\section{Growth and Nutritional Efficiency of Watermelon Plants Grown under Macronutrient Deficiencies}

\author{
Valéria Santos Cavalcante ${ }^{1}$, Renato de Mello Prado, \\ and Ricardo de Lima Vasconcelos \\ UNESP - Paulista State University, Department of Soils and Fertilization, \\ Via de Acesso Prof. Paulo Donato Castellane, s/n. 14884-900 Jaboticabal, \\ SP, Brazil

\section{Hilário Júnior de Almeida} \\ UFGD - Federal University of Grande Dourados, Rodovia Dourados/ \\ Itahum, s/n. 79.804-970 Dourados, MS, Brazil
}

\section{Thais Ramos da Silva}

UNESP - Paulista State University, Department of Soils and Fertilization, Via de Acesso Prof. Paulo Donato Castellane, s/n. 14884-900 Jaboticabal, SP, Brazil

Additional index words. Citrullus lanatus, plant nutrition, nutrient omission, nutrient accumulation, deficiency symptoms

\begin{abstract}
Biological damage caused by macronutrient deficiency in watermelon plants is still not known, and may lead to nutritional disorders and alterations in absorption and utilization efficiencies, depending on the evaluated nutrient. In this context, the aim of the present study was to evaluate the growth and nutritional efficiency of watermelon plants grown under macronutrient deficiencies. The experiments were carried out in pots containing an aerated nutrient solution. Treatments consisted of the nutrient solution containing (control) or lacking nitrogen $(-N)$, phosphorus $(-P)$, potassium $(-K)$, calcium ( $-\mathrm{Ca})$, magnesium $(-\mathrm{Mg})$, and sulfur $(-\mathrm{S})$, in a completely randomized design with three replications. At the end of the experiment with the onset of symptoms of deficiency, plant growth, green color index, nutrient accumulation, nutrient uptake, nutrient utilization efficiency, root density, and foliar deficiency symptoms were evaluated. P, K, Ca, Mg, and S deficiencies increased plant utilization efficiency and can potentiate watermelon development in environments deficient in these nutrients. The opposite was observed concerning nitrogen deficiency, because this condition induced greater biological damage, with low utilization efficiency, indicating the sensitivity of this species in low $\mathbf{N}$ conditions.
\end{abstract}

Watermelon is a noteworthy vegetable crop because it is produced in several countries worldwide. Watermelon consumption is important for humans, due to its high betacarotene and lycopene content and the fact that it is a rich source of antioxidants, which can prevent diseases (Charoensiri et al., 2009).

To meet market demands, it is essential to observe the nutritional status of plants during cultivation, especially regarding macronutrients, because, when present in adequate concentrations, they improve fruit visual, nutritional, and flavor quality. The identification of nutrient deficiency symptoms is relatively complex, due to the various biological functions and interactions that occur between nutrients and the environment, and even similar species exposed to nutritional stress have displayed differ-

Received for publication 12 Dec. 2018. Accepted for publication 25 Jan. 2019.

${ }^{1}$ Corresponding author. E-mail: valeria.cavalcante. agro@gmail.com. system. These studies are, therefore, essential, because watermelon cultivation in many regions worldwide is carried out in environments displaying low nutrient availability, and knowledge regarding nutritional efficiencies in these cases is useful for the nutritional management of the species.

Thus, taking into account the hypothesis that a) the size of dry matter mass accumulation loss in watermelon is dependent on the deficient nutrient, and b) nutritional efficiency can be increased depending on the deficient nutrient, the aim of the present study was to evaluate the growth and nutritional efficiency of watermelon plants grown in a nutrient solution lacking several essential macronutrients.

\section{Material and Methods}

The experiments were carried out in a greenhouse with watermelon plants of the Crimson sweet ${ }^{\circledR}$ variety, at the State University of São Paulo - Jaboticabal Campus (long. $21^{\circ} 15^{\prime} 22^{\prime \prime} \mathrm{W}$; lat. $\left.48^{\circ} 18^{\prime} 58^{\prime \prime} \mathrm{S}\right)$. During the experiment, meteorological data were measured, namely, average maximum temperature, of $30^{\circ} \mathrm{C} \pm 15^{\circ} \mathrm{C}$, and average minimum temperature, of $27{ }^{\circ} \mathrm{C} \pm 14{ }^{\circ} \mathrm{C}$, as well as average relative humidity of $45 \%$, and average irradiance of $1800 \mathrm{mmol} \cdot \mathrm{m}^{-2} \cdot \mathrm{s}^{-1}$.

Experimental design and plant treatments. The experimental design was completely randomized, comprising seven treatments and three replications. Treatments were as follows: growth in a complete nutrient solution (N, P, K, Ca, Mg, S, B, Cl, Cu, Fe, Mn, Mo, and $\mathrm{Zn}$ ) and in a solution lacking the following elements: $-\mathrm{N},-\mathrm{P},-\mathrm{K},-\mathrm{Ca},-\mathrm{Mg}$, and $-\mathrm{S}$. The plant pots were rotated weekly during the experiments to provide the same environmental conditions between treatments.

Experiments and plant evaluations. Watermelon seedlings $22 \mathrm{~d}$ after emergence were transplanted into polypropylene pots $\left(2.5 \mathrm{dm}^{3}\right)$ containing a complete nutrient solution prepared with deionized water, nutrient solution composition: 136.09 g. $\mathrm{L}^{-1} \quad \mathrm{KH}_{2} \mathrm{PO}_{4}, 101.11$ g. $\mathrm{L}^{-1} \mathrm{KNO}_{3}, 236.16 \mathrm{~g} \cdot \mathrm{L}^{-1} \mathrm{Ca}\left(\mathrm{NO}_{3}\right)_{2} \cdot 5 \mathrm{H}_{2} \mathrm{O}$, $247.47 \mathrm{~g} \cdot \mathrm{L}^{-1} \mathrm{MgSO}_{4} \cdot 7 \mathrm{H}_{2} \mathrm{O}$, and micronutrient solution $\left(2.86 \mathrm{~g} \cdot \mathrm{L}^{-1} \mathrm{H}_{3} \mathrm{BO}_{3} ; 0.08 \mathrm{~g} \cdot \mathrm{L}^{-1} \mathrm{Fe}-\right.$ EDDHA; $1.81 \mathrm{~g} \cdot \mathrm{L}^{-1} \mathrm{MnCl}_{2} \cdot 4 \mathrm{H}_{2} \mathrm{O} ; 0.10 \mathrm{~g} \cdot \mathrm{L}^{-1}$ $\mathrm{ZnCl}_{2} ; 0.04 \mathrm{~g} \cdot \mathrm{L}^{-1} \mathrm{CuCl}_{2} ; 0.02 \mathrm{~g} \cdot \mathrm{L}^{-1} \mathrm{H}_{2} \mathrm{MoO}_{4}$ $\mathrm{H}_{2} \mathrm{O}$ ), diluted to $50 \%$ and maintained for 4 days. After this period, the nutrient solutions (undiluted) were continuously aerated and changed weekly, and $\mathrm{pH}$ was adjusted daily between 5.0 and 6.0 , with a $0.1 \mathrm{~mol} \cdot \mathrm{dm}^{-3} \mathrm{HCl}$ solution or $1 \mathrm{~mol} \cdot \mathrm{dm}^{-3} \mathrm{NaOH}$ solution.

At the end of the experiments, the following biometric and physiological evaluations were carried out: plant height (from the plant neck to the apex of the last developed leaf); total number of leaves per plant; diameter of the main stem [measured at the bottom base with the aid of a Starrett (Athol, MA) 727$2001^{\circledR}$ digital caliper], and leaf area (measured with an LI-3100 Area Meter; LI-COR, Lincoln, NE). The green color index was evaluated in leaves exhibiting deficiency symptoms with the aid of a CCM200 device 
(Opti-Sciences, Hudson, NH). Plants were evaluated regarding possible nutrient deficiency symptoms weekly.

The roots were carefully separated, conditioned in bottles containing 20\% (v/v) alcohol and stored under refrigeration for subsequent density $\left(\mathrm{mm} \cdot \mathrm{cm}^{-3}\right.$ nutrient solution) and root dry matter mass (g) determinations. The Delta-T Devices (Cambridge, UK) LTD image analysis system was used to determine root length, area, and diameter.

The roots of each plant were stained with methylene blue for $\approx 2$ minutes and then placed on a water tray. The images were analyzed by a Hewlett Packard (Palo Alto, CA) Model 5C scanner. The image of each root system was subsequently evaluated by the Delta-TScan Root Analysis System software, which determined root length $(\mathrm{mm})$ by the Harris and Campbell (1989) method. Root density was calculated by dividing the determined root length by the nutrient solution volume $\left(\mathrm{mm} \cdot \mathrm{cm}^{-3}\right.$ nutrient solution). After density measurements, the roots were placed in paper bags and dried in a forced circulation oven at $65^{\circ} \mathrm{C} \pm 3{ }^{\circ} \mathrm{C}$, until constant mass.

The aerial portions and roots were separated, washed, and dried in a forced air circulation oven $\left(65^{\circ} \mathrm{C} \pm 3^{\circ} \mathrm{C}\right)$. Subsequently, macronutrient content determinations were performed, through the methodology described by Miyazawa et al. (2009).

Nutritional efficiency calculations. Macronutrient accumulation calculations for the aerial portions and roots of the watermelon plants were carried out using the dry mass data, allowing for subsequent calculations of absorption efficiency, according to Swiader et al. (1994), and utilization efficiency and translocation efficiency, according to Siddiqi and Glass (1981), through the following equations:

$$
\begin{gathered}
A E=\frac{T P N C}{R D M} \\
U E=\frac{T P D M^{2}}{T P N C} \\
T E=\frac{N C S}{T P N C},
\end{gathered}
$$

where $A E$ is absorption efficiency $\left(\mathrm{g} \cdot \mathrm{g}^{-1}\right) ; U E$ is utilization efficiency $\left(\mathrm{g} \cdot \mathrm{g}^{-1}\right)$; TE is translocation efficiency $\left(\mathrm{g} \cdot \mathrm{g}^{-1}\right)$; TPNC is total nutrient content in the plant ( $g$ per plant); $N C S$ is the nutrient content in the shoots $(\mathrm{g})$; $R D M$ is the root dry matter $(\mathrm{g})$; and $T P D M$ is the total dry matter produced $(\mathrm{g})$.

Data analyses. The experimental data were first submitted to an univariate analysis of variance, followed by comparison of the means by Tukey's test $(P \leq 0.05)$.

\section{Results and Discussion}

Macronutrient content, absorption efficiency, utilization efficiency, and translocation efficiency. Macronutrient omission from the nutrient solution decreased the accumulation of the

\begin{tabular}{|c|c|c|c|c|c|c|}
\hline Treatments & $\mathrm{N}$ & $\mathrm{P}$ & $\mathrm{K}$ & $\mathrm{Ca}$ & $\mathrm{Mg}$ & $\mathrm{S}$ \\
\hline & \multicolumn{6}{|c|}{ Aerial portion (mg per plant) } \\
\hline $\mathrm{CNS}$ & $203 \mathrm{a}$ & $21 \mathrm{a}$ & $177 \mathrm{a}$ & $104 \mathrm{a}$ & $20 \mathrm{ab}$ & $14 \mathrm{a}$ \\
\hline$-\mathrm{N}$ & $21 \mathrm{c}$ & $6 \mathrm{~b}$ & $21 \mathrm{~d}$ & $30 \mathrm{bc}$ & $5 \mathrm{c}$ & $2 \mathrm{c}$ \\
\hline$-\mathrm{P}$ & $136 \mathrm{~b}$ & $4 \mathrm{~b}$ & $95 \mathrm{c}$ & $44 \mathrm{bc}$ & $11 \mathrm{~b}$ & $7 \mathrm{~b}$ \\
\hline$-\mathrm{K}$ & $149 \mathrm{ba}$ & $14 \mathrm{a}$ & $29 \mathrm{~d}$ & $78 \mathrm{ab}$ & $16 \mathrm{ab}$ & $11 \mathrm{ab}$ \\
\hline$-\mathrm{Ca}$ & $158 \mathrm{ba}$ & $18 \mathrm{a}$ & $112 \mathrm{bc}$ & $19 \mathrm{c}$ & $27 \mathrm{a}$ & $11 \mathrm{ab}$ \\
\hline$-\mathrm{Mg}$ & $166 \mathrm{ba}$ & $17 \mathrm{a}$ & $127 \mathrm{~b}$ & $97 \mathrm{a}$ & $3 \mathrm{c}$ & $11 \mathrm{ab}$ \\
\hline$-\mathrm{S}$ & $184 \mathrm{ba}$ & $20 \mathrm{a}$ & $138 \mathrm{~b}$ & $107 \mathrm{a}$ & $15 \mathrm{ab}$ & $8 \mathrm{~b}$ \\
\hline \multirow[t]{2}{*}{ MSD } & 59 & 8 & 29 & 52 & 8 & 4 \\
\hline & \multicolumn{6}{|c|}{ Root (mg per plant) } \\
\hline $\mathrm{CNS}$ & $26 \mathrm{a}$ & $17 \mathrm{a}$ & $13 \mathrm{abc}$ & $28 \mathrm{a}$ & $3 \mathrm{a}$ & $4 \mathrm{a}$ \\
\hline$-\mathrm{N}$ & $4 \mathrm{~b}$ & $2 \mathrm{c}$ & $7 \mathrm{bc}$ & $1 \mathrm{~d}$ & $0.5 \mathrm{~b}$ & $1 \mathrm{c}$ \\
\hline$-\mathrm{P}$ & $19 \mathrm{~b}$ & $1 \mathrm{c}$ & $7 \mathrm{bc}$ & $2 \mathrm{~d}$ & $1.6 \mathrm{ab}$ & $2 b$ \\
\hline$-\mathrm{K}$ & $31 \mathrm{a}$ & $16 \mathrm{a}$ & $4 \mathrm{c}$ & $22 \mathrm{~b}$ & $3.7 \mathrm{a}$ & $3 a b$ \\
\hline$-\mathrm{Ca}$ & $27 \mathrm{a}$ & $5 \mathrm{bc}$ & $11 \mathrm{abc}$ & $1 \mathrm{~d}$ & $2.8 \mathrm{a}$ & $3 a b$ \\
\hline$-\mathrm{Mg}$ & $29 \mathrm{a}$ & $13 \mathrm{ab}$ & $18 \mathrm{ab}$ & $12 \mathrm{c}$ & $0.5 \mathrm{~b}$ & $3 a b$ \\
\hline$-\mathrm{S}$ & $31 \mathrm{a}$ & $14 \mathrm{a}$ & $23 \mathrm{a}$ & $16 \mathrm{bc}$ & $2.1 \mathrm{ab}$ & $2 b$ \\
\hline \multirow[t]{2}{*}{ MSD } & 18 & 7 & 12 & 6 & 2 & 2 \\
\hline & \multicolumn{6}{|c|}{ Whole plant (mg per plant) } \\
\hline CNS & $230 \mathrm{a}$ & $38 \mathrm{a}$ & $191 \mathrm{a}$ & $133 \mathrm{a}$ & $23 \mathrm{ab}$ & $18 \mathrm{a}$ \\
\hline$-\mathrm{N}$ & $25 \mathrm{c}$ & $8 \mathrm{c}$ & $28 \mathrm{~d}$ & $32 \mathrm{~b}$ & $5 \mathrm{~d}$ & $3 c$ \\
\hline$-\mathrm{P}$ & $156 \mathrm{~b}$ & $5 c$ & $102 \mathrm{c}$ & $46 \mathrm{~b}$ & $12 \mathrm{~cd}$ & $9 \mathrm{~b}$ \\
\hline$-\mathrm{K}$ & $181 \mathrm{ab}$ & $31 \mathrm{ab}$ & $33 \mathrm{~d}$ & $100 \mathrm{a}$ & $20 \mathrm{bc}$ & $14 \mathrm{ab}$ \\
\hline$-\mathrm{Ca}$ & $186 \mathrm{ab}$ & $24 \mathrm{~b}$ & $123 \mathrm{bc}$ & $21 \mathrm{~b}$ & $30 a$ & $14 \mathrm{ab}$ \\
\hline$-\mathrm{Mg}$ & $195 \mathrm{ab}$ & $30 \mathrm{ab}$ & $145 \mathrm{~b}$ & $109 \mathrm{a}$ & $3 \mathrm{~d}$ & $14 \mathrm{ab}$ \\
\hline$-\mathrm{S}$ & $216 \mathrm{ab}$ & $34 \mathrm{ab}$ & $161 \mathrm{ab}$ & $124 \mathrm{a}$ & $18 \mathrm{bc}$ & $10 \mathrm{~b}$ \\
\hline MSD & 71 & 12 & 39 & 52 & 9 & 6 \\
\hline
\end{tabular}

Table 1. Nutrient content of the aerial portions, roots, and whole watermelon plants of specimens grown in the complete nutrient solution (CNS) and in the macronutrient deficiency treatments. ${ }^{2}$

${ }^{2}$ Significant at $1 \%$ probability by the $F$ test. Means followed by the same letter in the column do not differ by Tukey's test at a $5 \%$ probability level.

$\mathrm{N}=$ nitrogen; $\mathrm{P}=$ phosphorus; $\mathrm{K}=$ potassium; $\mathrm{Ca}=$ calcium; $\mathrm{Mg}=$ magnesium; $\mathrm{S}=$ sulfur; $\mathrm{MSD}=$ minimum significant difference.

respective nutrient in the aerial portions, roots, and the entire plants (Table 1), indicating the precision of this study in demonstrating reduced plant absorption of the nutrient missing from the nutrient solution.

$\mathrm{N}$ and $\mathrm{P}$ omissions from the nutrient solution led to lower $\mathrm{N}, \mathrm{P}, \mathrm{K}, \mathrm{Ca}$, and $\mathrm{S}$ contents in the aerial portion and lower $\mathrm{N}, \mathrm{P}, \mathrm{Ca}$, and $\mathrm{S}$ in the roots compared with plants grown in the complete nutrient solution (Table 1). This indicates that $\mathrm{N}$ and $\mathrm{P}$ deficiencies cause a strong imbalance in the absorption of other macronutrients $(\mathrm{K}, \mathrm{Ca}, \mathrm{S})$ besides $\mathrm{N}$ and $\mathrm{P}$. This is due to the biological structural role of $\mathrm{N}$ in enzyme/ carrier establishment and P in ATP composition, both involved in nutrient absorption.

$\mathrm{N}, \mathrm{P}, \mathrm{Ca}, \mathrm{Mg}$, and $\mathrm{S}$ contents in the aerial portions and whole plant in individuals grown in the absence of $\mathrm{K}$ were similar to plants grown in the complete nutrient solution (Table 1), indicating that the omission of this nutrient does not lead to the imbalance of other macronutrients.

The accumulation patterns of $\mathrm{N}, \mathrm{P}, \mathrm{K}$, and $\mathrm{S}$ in the aerial portions of the watermelon plants in the absence of $\mathrm{Ca}$ were similar to those observed in the absence of $\mathrm{Mg}$ (Table 1), with $\mathrm{Ca}$ and $\mathrm{Mg}$ being accumulated in lower amounts when they were omitted from the nutrient solution, thus differing between each other and compared with the control treatment. This nutrient effect was also verified for roots and, consequently, for whole watermelon plants.

Lack of $\mathrm{S}$ decreased $\mathrm{K}$ and $\mathrm{S}$ contents in the aerial portions of the plants, as well as $\mathrm{Ca}$ and $\mathrm{S}$ contents in roots, with lower amounts of S only in the whole plants (Table 1).

The AE of the watermelon plants grown in the absence of $\mathrm{N}, \mathrm{P}, \mathrm{K}, \mathrm{Ca}, \mathrm{Mg}$, and $\mathrm{S}$ was lower than that of plants grown in the complete nutrient solution (Fig. 1A). The UE for $\mathrm{P}, \mathrm{K}, \mathrm{Ca}, \mathrm{Mg}$, and $\mathrm{S}$ was higher when these nutrients were omitted from the nutrient solution (Fig. 1B). The translocation efficiency (TE) between the complete nutrient solution and the treatments with omission of nutrients are similar (Fig. 1C). Similar results were observed for $\mathrm{P}, \mathrm{K}$, and $\mathrm{Ca}$ in Crotalaria juncea by Silva et al. (2016). The authors attributed this to a greater conversion capacity of the absorbed nutrients into dry matter as a plant strategy. In addition, the higher nutrient efficiency observed for $\mathrm{P}, \mathrm{K}$, and $\mathrm{Mg}$ in some species is due to the greater remobilization of these nutrients accumulated in plants in their inorganic forms (Maillard et al., 2015).

The lower AE and UE, along with the highest $\mathrm{TE}$ for $\mathrm{P}$ and $\mathrm{Ca}$ in plants grown under $\mathrm{P}$ deficiency (Fig. 1A-C) reinforce impairments in plant metabolism (Vance et al., 2003).

$\mathrm{N}, \mathrm{P}, \mathrm{Ca}$, and $\mathrm{Mg} \mathrm{AE}$ in plants grown under $\mathrm{K}$ deficiency were similar to those in plants grown in the complete nutrient solution (Fig. 1A). The same was observed for the TE of all macronutrients (Fig. 1C), whereas UE was different for $\mathrm{N}, \mathrm{K}$, and $\mathrm{Mg}$ relative to the complete nutrient solution (Fig. 1B), reflected in the accumulation of these nutrients (Table 1).

For plants grown under $\mathrm{Ca}$ deficiency, a greater accumulation of $\mathrm{Mg}$ in the aerial 
portions (Table 1) was observed among the macronutrients, resulting in a higher $\mathrm{AE}$ for this nutrient (Fig. 1A), and for higher TE of $\mathrm{Ca}$ (Fig. 1C). This increase indicates an electrical compensation to maintain chemical cell equilibrium because $\mathrm{Mg}^{2+}$ may be a partial substitute for $\mathrm{Ca}$ during $\mathrm{Ca}^{+2}$ deficiency conditions (Ramalho et al., 1995). In the deprivation of $\mathrm{Ca}$ of the nutrient solution there was even higher TE of P (Fig. 1C).

In plants grown under $\mathrm{S}$ deficiency, only the $\mathrm{AE}$ for $\mathrm{S}$ was lower compared with the complete nutrient solution treatment (Fig. 1A). The same was observed for UE for $\mathrm{N}$ and $\mathrm{S}$ (Fig. 1B). A close relationship between $\mathrm{S}$ and $\mathrm{N}$ exists, so when $\mathrm{S}$ is insufficient, the UE for $\mathrm{N}$ is limited, due to the participation of both elements in protein formation (Schonhof et al., 2007).

In this study, macronutrient deficiency in watermelon led to decreased $\mathrm{AE}$ and decreased UE only for $\mathrm{N}$, whereas the other nutrients displayed increased UE. In relation to TE, the translocation of $\mathrm{P}$ and $\mathrm{Ca}$ was higher and $\mathrm{S}$ and $\mathrm{K}$ were smaller. Among the macronutrients, the omission of $\mathrm{N}$ was the one that most influenced the translocation of other nutrients to the other parts of the plant. This may indicate that this plant has a low tolerance to $\mathrm{N}$-deficient environments, and the contrary for the other evaluated macronutrients.

Aerial and root growth. The aerial portion of the watermelon plants grown in the nutrient solution lacking $\mathrm{N}$ exhibited lower growth (plant height, number of leaves, leaf area, and stem diameter) and leaf green color index compared with plants grown in the complete nutrient solution (Table 2). $\mathrm{N}$ scarcity is mainly associated with decreases in leaf area, leading to lower leaf photosynthetic capacity (Zhao et al., 2005). The root system also presented lower $\mathrm{N}$ content when grown under lack of N. This reinforces the importance of this nutrient in plant growth as an integral part of protein molecules (Stefanelli et al., 2010).

$\mathrm{P}$ deficiency led to decreased leaf and increased root areas in comparison with plants grown under the complete nutrient solution, as well as higher root density compared with $\mathrm{N}, \mathrm{Ca}$, and $\mathrm{Mg}$ omission treatments (Table 2). Higher root growth (aerial and density) is a plant strategy used to improve acquisition and use in environments exhibiting P limitations (Vance et al., 2003). In addition, $P$ deficiency promotes losses in several plant variables, due to lower cellular expansion and division, observed in different species (Castro et al., 2015; Chiera et al., 2002; Kavanova et al., 2006).
Decreases in stem diameter, leaf area, and root density and length in watermelon plants were observed when plants were grown under $\mathrm{K}$ deficiency (Table 2). The lower
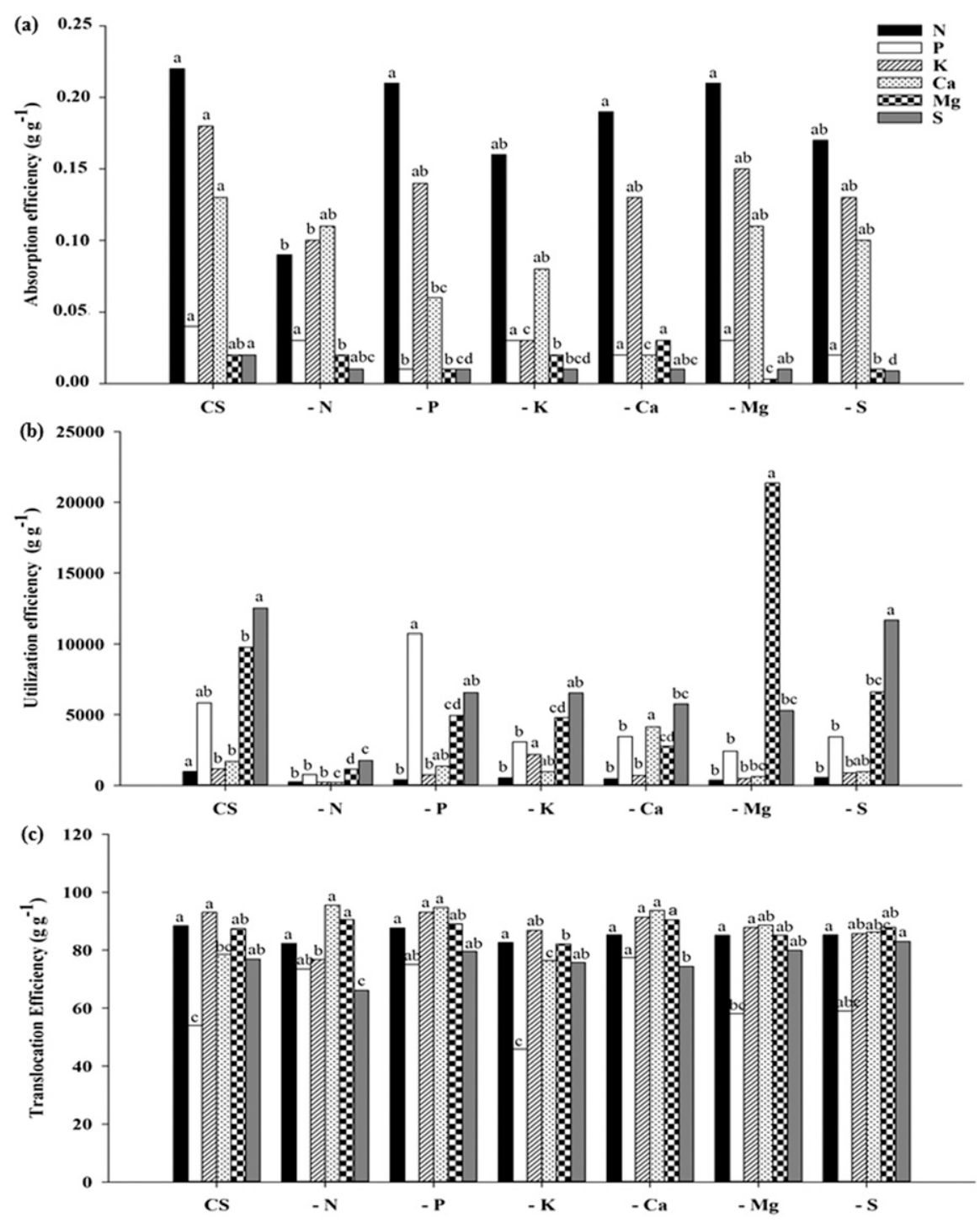

Fig. 1. Absorption (A), utilization (B), and translocation (C) efficiencies for nitrogen (N), phosphorus (P), potassium $(\mathrm{K})$, calcium $(\mathrm{Ca})$, magnesium $(\mathrm{Mg})$, and sulfur $(\mathrm{S})$ in watermelon plants due to macronutrient omission compared with the controls (CS, complete solution) grown in the complete nutrient solution. The same letters in the graph bars indicate that the means do not differ by Tukey's test at a probability level of $5 \%$. For absorption efficiency minimum significant difference (MSD)-N: 0.08 ; MSD-P: 0.01; MSD-K: 0.05; MSD-Ca: 0.06; MSD-Mg: 0.01; MSD-S: 0.005 . For utilization efficiency MSD-N: 340.6; MSD-P: 5088.9; MSD-K: 258.1; MSD-Ca: 1007.1; MSD-Mg: 4701.5; MSD-S: 6468.2. For translocation efficiency MSD-N: 8.56; MDS-P: 18.78; MDS-K: 10.77; MDSCa: 11.56; MDS-Mg: 8.23; MDS-S: 7.52.

Table 2. Plant height (PH), number of leaves (NL), stem diameter (SD), leaf area (LA), green color index (GCI), root area (RA), root length (RL), and root density (RD) of watermelon plants for each macronutrient deficiency treatment. ${ }^{z}$

\begin{tabular}{|c|c|c|c|c|c|c|c|c|}
\hline Treatment & $\mathrm{PH}(\mathrm{cm})$ & NL & $\mathrm{SD}(\mathrm{mm})$ & $\mathrm{LA}\left(\mathrm{cm}^{2}\right)$ & GCI & $\mathrm{RA}\left(\mathrm{cm}^{2} \cdot \mathrm{cm}^{-3}\right)$ & $\mathrm{RL}\left(\mathrm{cm} \cdot \mathrm{cm}^{-3}\right)$ & $\mathrm{RD}\left(\mathrm{mm} \cdot \mathrm{cm}^{-3}\right)$ \\
\hline$\overline{\mathrm{CNS}}$ & $166 \mathrm{a}$ & $32 \mathrm{a}$ & $7.29 \mathrm{a}$ & $1855.4 \mathrm{a}$ & $18.2 \mathrm{ab}$ & $0.15 \mathrm{~b}$ & $12.7 \mathrm{a}$ & $162.7 \mathrm{a}$ \\
\hline$-\mathrm{N}$ & $63 \mathrm{~b}$ & $12 \mathrm{c}$ & $5.35 \mathrm{c}$ & $183.8 \mathrm{~d}$ & $4.9 \mathrm{~d}$ & $0.08 \mathrm{c}$ & $2.4 \mathrm{~b}$ & $9.6 \mathrm{c}$ \\
\hline$-\mathrm{P}$ & $167 \mathrm{a}$ & $24 \mathrm{ab}$ & $6.65 \mathrm{ab}$ & $471.9 \mathrm{bd}$ & $14.3 \mathrm{bc}$ & $0.55 \mathrm{a}$ & $6.2 \mathrm{ab}$ & $62.1 \mathrm{~b}$ \\
\hline$-\mathrm{K}$ & $162 \mathrm{a}$ & $28 \mathrm{ab}$ & $5.44 \mathrm{c}$ & $928.8 \mathrm{bc}$ & $19.4 \mathrm{ab}$ & $0.13 \mathrm{~b}$ & $3.2 \mathrm{~b}$ & $46.6 \mathrm{~b}$ \\
\hline$-\mathrm{Ca}$ & $131 \mathrm{a}$ & $22 \mathrm{abc}$ & $6.10 \mathrm{bc}$ & $1353.5 \mathrm{ab}$ & $23.5 \mathrm{a}$ & $0.02 \mathrm{c}$ & $0.6 \mathrm{c}$ & $5.9 \mathrm{c}$ \\
\hline$-\mathrm{Mg}$ & $164 \mathrm{a}$ & $30 \mathrm{ab}$ & $5.11 \mathrm{c}$ & $839.3 \mathrm{bc}$ & $7.3 \mathrm{~cd}$ & $0.02 \mathrm{c}$ & $0.5 \mathrm{c}$ & $5.8 \mathrm{c}$ \\
\hline$-\mathrm{S}$ & $158 \mathrm{a}$ & $19 \mathrm{bc}$ & $6.61 \mathrm{ab}$ & $1181.4 \mathrm{~b}$ & $15.3 \mathrm{~b}$ & $0.33 \mathrm{a}$ & $9.5 \mathrm{ab}$ & $36.0 \mathrm{~b}$ \\
\hline MSD & 46.5 & 11.0 & 1.06 & 603.7 & 7.3 & 0.27 & 9.9 & 54.9 \\
\hline
\end{tabular}

${ }^{\mathrm{z}}$ Significant at $1 \%$ probability by the $F$ test. Means followed by the same letter in the column do not differ by Tukey's test at a $5 \%$ probability level. $\mathrm{N}=$ nitrogen; $\mathrm{P}=$ phosphorus; $\mathrm{K}=$ potassium; $\mathrm{Ca}=$ calcium; $\mathrm{Mg}=$ magnesium; $\mathrm{S}=$ sulfur; $\mathrm{MSD}=$ minimum significant difference. 
growth of the aerial portion was probably a reflection of the importance of this element in the stomatal opening process, with an effect on photosynthesis (Cavalcante et al., 2015). With regard to the root system, lack of $\mathrm{K}$ induces higher ethylene production, leading to increases in free radical species in roots and, consequently, lower growth (Schachtman, 2015).

In the absence of $\mathrm{Ca}$, plants presented a decrease in stem diameter in relation to plants grown in the complete nutrient solution treatment (Table 2). The highest effect of $\mathrm{Ca}$ omission was observed in the root system, which exhibited smaller area, length, and density in relation to plants grown in the complete nutrient solution, which can be attributed to the important role of this nutrient in cell elongation and mitotic division (Prado, 2008).

Concerning the absence of $\mathrm{Mg}$, decreases in stem diameter, green color index, and leaf area were detected when compared with plants grown in the complete nutrient solution (Table 2). Mg is the central atom of the chlorophyll molecule, and in its absence, rapid chlorophyll degradation occurs, leading to decreases in the leaf green color index and aerial foliar portions, and, consequently lower photosynthesis rates (Farhat et al., 2014; Hawkesford et al., 2012). The root system of watermelon plants grown under $\mathrm{Mg}$ deficiency also presented lower growth (area, length, and density), similar to that observed in plants grown under $\mathrm{Ca}$ deficiency.

In the absence of S, leaf area, number of leaves, and root density were decreased, whereas a larger root area was detected in relation to plants grown in the complete nutrient solution (Table 2). This is due to the lower effect of S deficiency, because only lower $\mathrm{K}$ and $\mathrm{S}$ contents were detected in the aerial portion, whereas $\mathrm{Ca}$ and $\mathrm{S}$ were lower in roots (Table 1). The lower Ca content in the roots observed when plants were grown under S deficiency was probably the cause of the decreased root density. In addition, the $\mathrm{UE}$ for $\mathrm{P}, \mathrm{K}, \mathrm{Ca}, \mathrm{Mg}$, and $\mathrm{S}$ in this condition was similar to plants grown in the complete nutrient solution (Fig. 1B).

Shoot and root dry matter. Macronutrient deficiency led to decreased aerial portion dry matter mass compared with plants grown under the complete nutrient solution treatment, with the greatest effect observed for the $\mathrm{N}$ omission condition (Fig. 2A). This is due to the decrease in macronutrient content (Table 1) and growth variables (Table 2), that is, greater nutrient utilization efficiency when $\mathrm{N}$ was omitted (Fig. 1B) was not enough to maintain dry matter mass production.

Macronutrient deficiency in watermelon plants further impaired the production of the aerial portion dry matter mass, to the detriment of the root dry matter mass, which was influenced only by lack $-\mathrm{N}$ (Fig. 2A), but reflected in the dry matter mass of the entire plant (Fig. 2B).

The lower $\mathrm{N}$ accumulation (Table 1) observed due to the omission of this element in the nutrient solution implies reduction of the mesophilic capacity for net carbon assimilation at the cellular level, leading to lower investments in the photosynthetic apparatus (Boussadia et al., 2010; Cechin and Fumis, 2004). This fact, along with the imbalance observed for the other evaluated nutrients (Table 1), leads to decreases in the energy available for investment in the aerial portion and root dry mass (Fig. 2A), as well as whole plant dry mass (Fig. 2B).

In the absence of $\mathrm{P}$, decreases in the aerial portion and root system dry matter mass (Fig. 2A) were observed, also reflecting the lower accumulation of the other evaluated macronutrients in relation to the complete nutrient solution treatment (Table 1). This indicates nutritional imbalances, even when only the leaf area was reduced in relation to the other evaluated plant growth variables (Table 2).

The decreases in dry matter mass observed in the $\mathrm{K}$ omission treatment in relation to the complete treatment (Fig. 2) are mainly related to one of the main functions of this nutrient, which is to assist in photoassimilated transport between the source and the drain (Cakmak, 1994; Hawkesford et al., 2012).

Despite the lower root growth observed in the $\mathrm{Ca}$ and $\mathrm{Mg}$ omission treatments (Table 2), the root system dry matter mass was similar to the complete nutrient solution treatment (Fig. 2A). The greater $\mathrm{Ca}$ and $\mathrm{Mg}$ deficiency effects were observed as decreased aerial portion dry matter mass compared with the root. This can be related to carbon partitioning when forming the organ (Gransee and Führs, 2013).

The dry matter mass in the aerial portion of plants grown in lack of $\mathrm{S}$ conditions was lower compared with plants grown in the complete nutrient solution treatment (Fig. 2A). The aerial portion also exhibited more damage than the roots, because plant cell walls and chloroplasts are composed of sulfolipids,
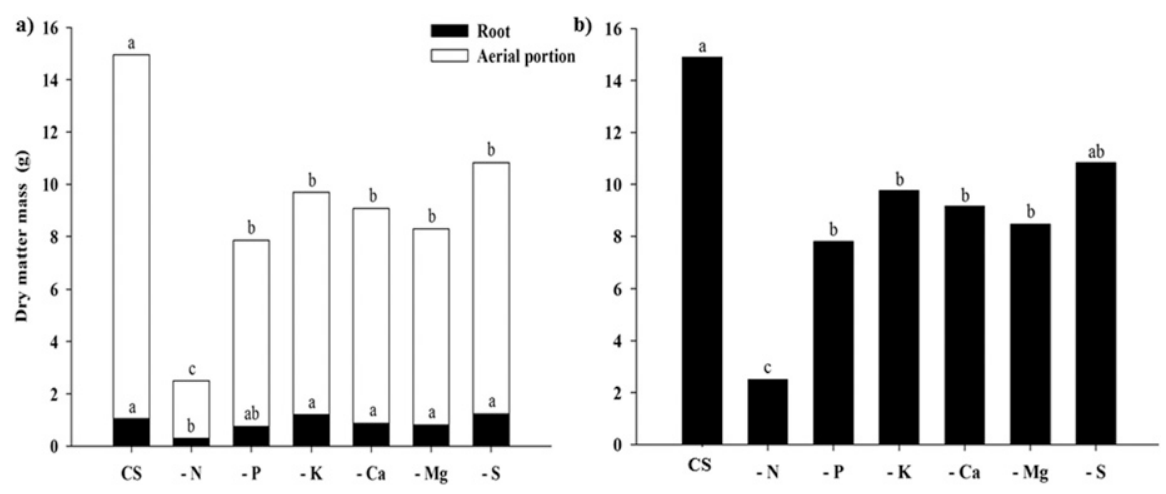

Fig. 2. Dry matter mass in watermelon aerial portions and roots (A), and in the entire watermelon plant (B), due to macronutrient omission compared with the controls (CS, complete solution) grown in the nutrient solution. Same letters in the bars indicate that the averages do not differ by Tukey's test at a probability level of 5\%. MSD (minimum significant difference)-shoot: 4.04; MSD-root: 0.65; MSDwhole plant: 4.59 .

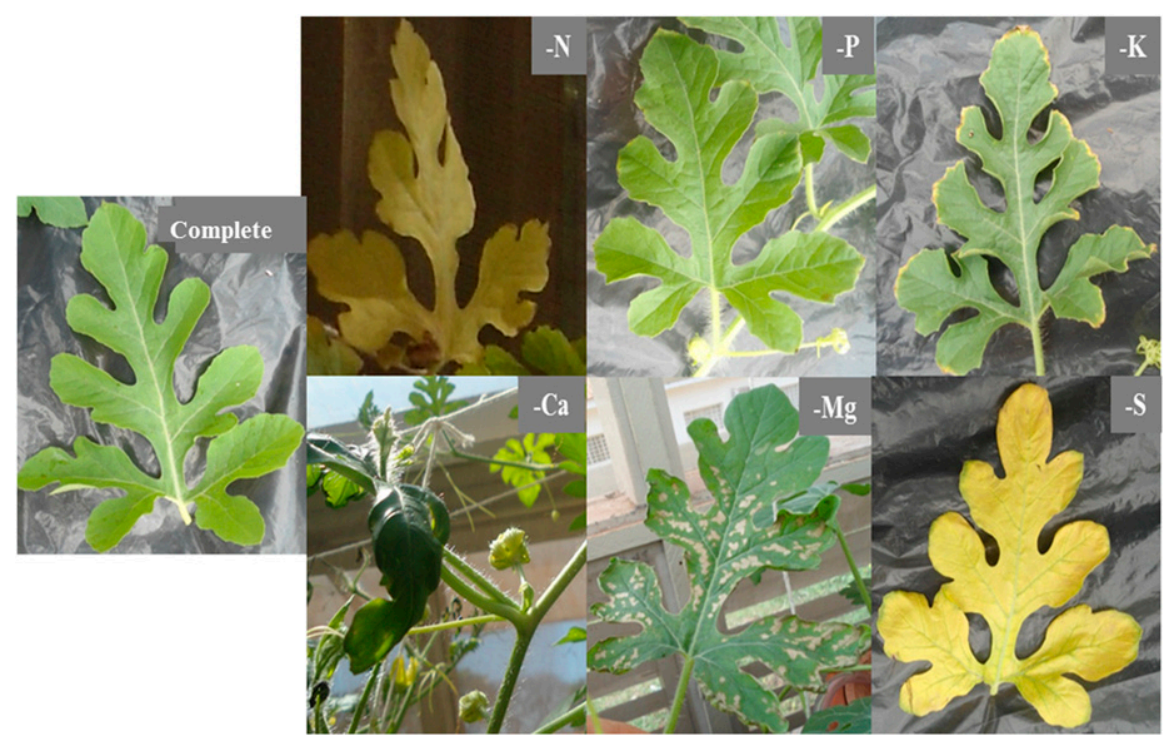

Fig. 3. Nutritional deficiency symptoms in watermelon related to lack of nitrogen $(-\mathrm{N})$, phosphorus $(-\mathrm{P})$, potassium $(-\mathrm{K})$, magnesium $(-\mathrm{Mg})$ and sulfur $(-\mathrm{S})$ in old leaves and calcium $(-\mathrm{Ca})$ in young leaves compared with plants grown in the complete nutrient solution (with no macronutrient deficiency). 
whereas cell membranes are composed of phospholipids in nonphotosynthetic tissues (Imsande, 1998).

Nutritional deficiency symptoms in leaves. The visual symptoms of macronutrient deficiency (Fig. 3) in leaves appeared at $7 \mathrm{~d}$ for $\mathrm{Mg}$ in older leaves, which presented necrotic spots in the limbus, followed by foliar abscission; at $12 \mathrm{~d}$ for $\mathrm{N}$, with yellowing of older leaves, followed by yellowing of all leaves; at $24 \mathrm{~d}$ for $\mathrm{Ca}$, leading to apical death of the plants, with leaf shading and fast drying of the extremities; and at $24 \mathrm{~d}$ for S, with yellowing of older leaves and a green color at the ribs. For P, no visual symptoms were observed (42 d), whereas for K, symptoms appeared at $40 \mathrm{~d}$, with burning on the edges of older leaves, while leaf limbs exhibited a dark green color.

These symptoms were similar to those observed by Costa et al. (2017), differing only concerning the time they appeared. These authors omitted N, P, Ca, and Mg from the nutrient solution during the fruiting phase, corresponding to $38 \mathrm{~d}$ after sowing, whereas $\mathrm{K}$ omission from the nutrient solution was carried out $49 \mathrm{~d}$ after sowing. In the present study, the nutrient omissions were carried out at $26 \mathrm{~d}$ after sowing. In addition, those authors verified early symptoms of macronutrient deficiency for the $\mathrm{N}$ and $\mathrm{Ca}$ omission treatments.

$\mathrm{P}, \mathrm{K}, \mathrm{Ca}, \mathrm{Mg}$, and $\mathrm{S}$ deficiencies in watermelon plants led to increased utilization efficiencies and may lead to greater development in environments exhibiting a lack of these nutrients. The opposite was observed for $\mathrm{N}$ deficiency, because this condition induced greater biological damage, with low UE, indicating the sensitivity of the evaluated species in environments displaying low $\mathrm{N}$ content.

\section{Literature Cited}

Berry, W. 2016. Symptoms of deficiency in essential minerals. In: L. Taiz and E. Zeiger (eds.). Plant physiology Online. 3 Oct. 2016. <http:// 6e.plantphys.net/topic05.01.html .

Boussadia, O., K. Steppe, H. Zgallai, S. Ben, E. Hadj, M. Braham, R. Lemeur, and M.C. Van Labeke. 2010. Effects of nitrogen deficiency on leaf photosynthesis, carbohydrate status and biomass production in two olive cultivars
'Meski' and 'Koroneiki'. Scientia Hort. 123:336-342.

Cavalcante, V.S., R.M. Prado, H.J. Almeida, F.J.R. Cruz, and D.M.M. Santos. 2015. Gaseous exchanges, growth and foliar anatomy of sugarcane plants grown in potassium $(\mathrm{K})$ deprived nutrient solution. Austral. J. Crop Sci. 9:577584.

Cakmak, I. 1994. Activity of ascorbate-dependent $\mathrm{H}_{2}$ $\mathrm{O}_{2}$-scavenging enzymes and eafchlorosis are enhanced in magnesium- and potassium-deficient leaves, but not in phosphorus-deficient leaves. J. Expt. Bot. 45:1259-1266.

Castro, A.C.R.D., L.G. Willadino, V. Loges, M.F.A.D. Castro, and F.A.S.D. Aragão. 2015. Macronutrients deficiency in Heliconia psittacorum x Heliconia spathocircinata 'Golden Torch'. Rev. Cienc. Agron. 46:258-265.

Cechin, I. and T.F. Fumis. 2004. Effect of nitrogen supply on growth and photosynthesis of sunflower plants grown in the greenhouse. Plant Sci. 166:1379-1385.

Charoensiri, R., R. Kongkachuichai, S. Suknicom, and P. Sungpuag. 2009. Beta-carotene, lycopene, and alpha-tocopherol contents of selected Thai fruits. Food Chem. 113:202-207.

Chiera, J., J. Thomas, and T. Rufty. 2002. Leaf initiation and development in soybean under phosphorus stress. Exp. Bot. 53:473-481.

Costa, C.L., C.V.M. Vergara, A.B. Cecílio Filho, N.C. Seno, and N.C. Seno. 2017. Sintomas de defciências de macronutrientes em melancieira. Comun. Sci. 8:80-92.

Farhat, N., M. Rabhi, M. Krol, Z. Barhoumi, A.G Ivanov, A. McCarthy, C. Abdelly, A. Smaoui, and N.P.A. Hüner. 2014. Starch and sugar accumulation in Sulla carnosa leaves upon $\mathrm{Mg}^{2+}$ starvation. Acta Physiol. Plant. 36:2157-2165.

Gransee, A. and H. Führs. 2013. Magnesium mobility in soils as a challenge for soil and plant analysis, magnesium fertilization and root uptake under adverse growth conditions. Plant Soil 368:5-21.

Harris, G.A. and G.S. Campbell. 1989. Automated quantification of roots using a simples image analyser. Agron. J. 81:935-938.

Hawkesford, M., W. Horst, T. Kichey, H. Lambers, J. Schjoerring, I.S. Møller, and P. White. 2012. Functions of macronutrients: Potassium and magnesium, p. 165-189. In: H. Marschner (ed.). Mineral nutrition of higher plants. Academic Press, Amsterdam, Netherlands.

Imsande, J. 1998. Iron, sulfur, and chlorophyll deficiencies: A need for an integrative approach in plant physiology. Physiol. Plant. 103:139-144.
Kavanova, M., F.A. Lattanzi, A.A. Grimoldi, and H. Schnyder. 2006. Phosphorus deficiency decreases cell division and elongation in grass leaves. Plant Physiol. 141:766-775.

Maillard, A., S. Diquélou, V. Billard, P. Laîné, M. Garnica, M. Prudent, J.-M. Garcia-Mina, J.-C. Yvin, and A. Ourry. 2015. Leaf mineral nutrient remobilization during leaf senescence and modulation by nutrient deficiency. Front. Plant Sci. 6:1-15.

Miyazawa, M., M.A. Pavan, T. Muraoka, C.A.F.S. Carmo, and W.J. Melo. 2009. Análise química de tecido vegetal, p. 191-233. In: F.C. Silva (ed.). Manual de análises químicas de solos, plantas e fertilizantes. Brasília, BR.

Prado, R.M. 2008. Nutrição de plantas. Jaboticabal, BR

Ramalho, J.C., M.C. Rebelo, M.E. Santos, M.L. Antunes, and M.A. Nunes. 1995. Effects of calcium deficiency on coffea arabica. Nutrient changes and correlation of calcium levels with some photosynthetic parameters. Plant Soil 172:87-96.

Schachtman, D.P. 2015. The Role of ethylene in plant responses to $\mathrm{K}^{+}$deficiency. Front. Plant Sci. 6:1-4.

Schonhof, I., D. Blankenburg, S. Müller, and A. Krumbein. 2007. Sulfur and nitrogen supply influence growth, product appearance, and glucosinolate concentration of broccoli. J. Plant Nutr. Soil Sci. 170:65-72.

Siddiqi, M.Y. and A.D. Glass. 1981. Utilization index: A modified approach to the estimation and comparison of nutrient utilization efficiency in plants. J. Plant Nutr. 4:289-302.

Silva, G.P., P.R. Mello, L.R. Moda, and S.L.I.O. Silva. 2016. Growth, nutrient accumulation and nutritional efficiency of sunn hemp in function of nutrient omission. Afr. J. Agr. Res. 11:494499.

Stefanelli, D., I. Goodwin, and R. Jones. 2010. Minimal nitrogen and water use in horticulture: Effects on quality and content of selected nutrients. Food Res. Intl. 43:1833-1843.

Swiader, J.M., Y. Chyan, and F.G. Freiji. 1994. Genotypic differences in nitrate uptake and utilization efficiency in pumpkin hybrids 1 . J. Plant Nutr. 17:1687-1699.

Vance, C.P., C. Uhde-Stone, and D.L. Allan. 2003. Phosphorus acquisition and use: Critical adaptations by plants for securing a nonrenewable resource. New Phytol. 157:423-447.

Zhao, D., K.R. Reddy, V.G. Kakani, and V.R. Reddy. 2005. Nitrogen deficiency effects on plant growth, leaf photosynthesis, and hyperspectral reflectance properties of sorghum. Eur. J. Agron. 22:391-403. 